ISSN: 2302-8556

E-Jurnal Akuntansi Universitas Udayana

Vol.26.1.Januari (2019): 175-190

DOI: https://doi.org/10.24843/EJA.2019.v26.i01.p07

\title{
Analisis Volume untuk Perbandingan Minat Investor Disekitar Ex-Dividend Date pada Emiten Kategori LQ-45 Tahun 2017
}

\author{
Byantoro Istahargyo ${ }^{1}$ \\ Made Gede Wirakusuma ${ }^{2}$ \\ ${ }^{1,2}$ Fakultas Ekonomi dan Bisnis Universitas Udayana (Unud), Bali, Indonesia \\ e-mail: Byantoroistahargyo@gmail.com
}

\begin{abstract}
ABSTRAK
Terdapat dua pendekatan yang menggambarkan keinginan investor yakni Bird in The Hand dan Tax Preference. Penelitian ini bertujuan untuk melihat pendekatan apa yang cenderung lebih di minati oleh investor Indonesia. Penelitian ini dilakukan pada volume saham perusahaan yang terdaftar dalam indeks LQ-45 yang terdaftar di Bursa Efek Indonesia (BEI) pada tahun 2017. Perusahaan yang dijadikan sampel dipilih menggunakan metode purposive sampling sehingga diperoleh sampel sebanyak 46 perusahaan. Volume perdagangan saham diukur dengan Trading Volume Activity (TVA). Teknik analisis yang digunakan dalam penelitian ini adalah uji statistik deskriptif, uji normalitas, paired sample $\mathrm{t}$ test dan wilcoxon sign rank test.Berdasakan hasil pengujian dapat disimpulkan bahwa terdapat perbedaan yang signifikan antara volume perdagangan saham sebelum dan sesudah ex-dividend date. Hal ini menunjukkan bahwa peristiwa ex-dividend date mempengaruhi aktivitas volume perdagangan saham dan direspon oleh investor.
\end{abstract}

Kata kunci : TVA, Volume Perdagangan Saham, Ex-Dividend Date.

\begin{abstract}
There are two approaches that describe investor desires, namely Bird in The Hand and Tax Preference. This study aims to see what approaches tend to be more interested by Indonesian investors. This research was conducted on the volume of shares of companies listed in the LQ-45 index listed on the Indonesia Stock Exchange (IDX) in 2017. The companies that were sampled were selected using purposive sampling method to obtain a sample of 46 companies. Stock trading volume is measured by Trading Volume Activity (TVA). The analysis technique used in this study is descriptive statistical test, normality test, paired sample $t$ test and wilcoxon sign rank test. Test results can be concluded that there is a significant difference between stock trading volume before and after the exdividendd date. This shows that the ex-dividend date event affected the activity of stock trading volume and responded by investors.

Keywords: TVA, Volume of Stock Trading, Ex-Dividend Date.
\end{abstract}

\section{PENDAHULUAN}

Investasi merupakan suatu cara yang pada umumnya digunakan oleh individu yang bertujuan agar mendapatkan tambahan kekayaan ataupun manfaat dimasa mendatang. Perubahan zaman mendorong terjadinya perubahan pada model investasi yang sebelumnya konvensional berubah menjadi pasar modal. Antolis dan Dossugi (2008) menyatakan terdapat beberapa instrumen investasi 
konvensonal yang umum digunakan oleh masyarkat seperti: tanah, rumah, deposito. Perkembangan zaman mendorong perubahan dari investasi konvensional menjadi invastasi modern ( capital market). Perubahan tersebut dikarenakan oleh hasil investasi yang lebih tinggi diatas rata - rata dibandingkan investasi konvensional seperti deposito.

Penggunaan instrumen investasi pasar modal dilakukan dengan cara investor menginvestasikan uangnya dalam bentuk pembelian saham perusahaan pada perusahaan yang listing di pasar modal. Return yang didapatkan investor atas pembelian saham perusahaan terdapat dua jenis,yaitu berupa capital gain dan Dividend. Pendapat serupa juga dikemukakan oleh Suharli (2005) Ekspetasi dari para investor terhadap investasinya adalah memperoleh return (tingkat pengembalian) sebesar-besarnya dengan risiko tertentu, return tersebut dapat berupa capital gain ataupun Dividend untuk investasi pada saham. Berdasarkan hal tersebut maka terbentuk logika berpikir bahwa terdapat 2 jenis investor, yaitu investor yang mengharapkan return berupa capital gain dan investor yang mengharapkan return burupa Dividend.

Fajaria (2015) berpendapat bahwa kebijakan Dividend perusahaan akan mendapatkan respon dari investor. Berdasarkan hal tersebut investor dengan tingkat toleransi risiko rendah (risk averse) cenderung memilih return yang memiliki kepastian dan dengan tingkat risiko yang lebih rendah berupa Dividend. Dividend yang diterima pada saat ini akan mempunyai nilai yang lebih tinggi daripada capital gain yang diterima dimasa yang akan datang, sehingga investor dengan tingkat toleransi risiko rendah akan lebih menyukai Dividend 
dibandingkan capital gain (Prihantoro, 2003). Pendapat tersebut didukung oleh teori dari Myron Gordon dan John Lintner (1962) yaitu Bird In The Hand Theory, teori tersebut mengatakan investor lebih menyukai pembayaran Dividend yang bersifat pasti dan memiliki risiko yang lebih rendah dibandingkan dengan capital gain, Alasan yang sering dikemukakan dalam memilih Teori Bird In The Hand ini karena ada anggapan bahwa mendapat Dividend tinggi saat ini resikonya lebih kecil daripada mendapat capital gain di masa yang akan datang.

Putra dan Arfan (2013) Investasi pada saham memiliki karakteristik high risk-high return. Artinya, saham merupakan surat berharga yang memberikan peluang keuntungan tinggi namun juga berpotensi risiko tinggi. Berdasarkan pendapat tersebut investor dengan toleransi risiko yang tinggi (risk taker) cenderung memilih return dalam bentuk capital gain. Capital gain yang diterima dimasa yang akan datang dianggap akan memberikan return yang lebih tinggi dimasa mendatang dikarenakan capital gain memiliki biaya pajak yang lebih rendah dibanding dengan Dividend. Pendapat tersebut didukung oleh teori Tax Preference Theory, teori ini menyatakan adanya pembayaran pajak yang lebih tinggi terhadap Dividend daripada capital gain, sehinga investor dengan tingkat risiko yang lebih tinggi (risk taker) lebih menyukai capital gain karena pajak yang lebih kecil walaupun risikonya lebih tinggi. Hal ini terjadi jika ada perbedaan antara tarif pajak personal atas pendapatan Dividend dan capital gain. Apabila tarif pajak Dividend lebih tinggi daripada pajak capital gain, maka investor akan lebih senang jika laba yang diperoleh perusahaan tetap ditahan di perusahaan, untuk mendanai investasi yang dilakukan perusahaan. Dengan demikian di masa 
yang akan datang diharapkan terjadi peningkatan capital gain yang tarif pajaknya lebih rendah.

Stice dan Suharli (2006:245) mengartikan dividen sebagai pembagian laba kepada para pemegang saham perusahaan sebanding dengan jumlah saham yang dipegang oleh masing-masing pemilik. Sedangkan menurut Pasar Modal Bursa Efek Jakarta (2005:4) mendifinisikan, dividen merupakan keuntungan perusahaan dibagikan kepada pemegang saham. Berdasarkan beberapa definisi tersebut dapat disimpulkan dividen merupakan laba bersih perusahaan yang dibagikan setiap periode tertentu dalam bentuk kas maupun saham yang berasal dari sumber aliran kas perusahan yang berasal dari laba bersih perusahaan. Sehingga apabila perusahaan mengalami kerugian perusahaan tersebut tidak akan membagikan dividennya, selain itu dividen juga dibagikan setelah melalui Rapat umum pemegang saham (RUPS) yang akan memutuskan apakah perusahaan tersebut membagikan dividen maupun tidak dan berapa besaran daripada dividen itu sendiri.

Volume perdagangan saham merupakan jumlah lembar saham yang diperdagangkan secara harian (Magdalena, 2004). Perkembangan volume perdagangan saham mencerminkan kekuatan antara penawaran dan permintaan yang Frekuensi perdagangan menggambarkan berapa kali saham suatu emiten diperjualbelikan dalam kurun waktu tertentu. Minat pelaku pasar pada perdagangan saham tertentu akan dapat dilihat disini

Tujuan perusahan melakukan dividen adalah mebagikan keuntungan kepada pemilik perusahannya sesuai dengan tujuan perusahan yaitu memakmurkan 
pemiliknya. Selain itu pembagian dividen juga menunjukan kondisi keuangan dan fundamental perusahan yang baik yang akan memberigan dampak bagi perusahan yaitu naiknya reputasi perusahaan karena telah dapat memakmurkan pemegang sahamnya. Mengapa menggunakan LQ45 karena indeks LQ45 merupakan indeks paling liquid yang ada di Bursa Efek Indonesia sehingga membuat respon pasar lebih cepat pada saham saham yang tergabung dalam indeks tersebut.

Berdasarkan pemaparan diatas dapat disimpulkan bahwa teori Bird In The Hand Theory menurut Myron Gordon dan John Lintner lebih mengarah akan terjadinya perubahan volume yang cenderung naik sebelum ex-Dividend date dan menurun setelah ex-Dividend date karena kebijakan Dividend oleh suatu emiten yang membagikan deviden kepada investornya yang membuat investor menyukai return yang pasti akan melakukan akumulasi sebelum ex-Dividend date dan menjual setelah ex-Dividend date, sedangkan pada teori Tax Preference Theory berpendapat bahwa pembagian Dividendd akan menyebabkan perubahan volume saham sebelum dan sesudah ex-Dividend date. Hal ini menyebabkan volume dan frekuensi sebelum ex-Dividend date cenderung rendah dan sesudah ex-Dividend date akan cenderung meningkat.

Penelitian terdahulu yang telah banyak dilakukan menyatakan bahwa volume dapat diproksikan sebagai bentuk reaksi pasar terkait dengan aksi pembagian Dividend tunai oleh perusahan, dimana terdapat dua jenis investor yang menyukai return terhadap investasinya berupa mendapatkan Dividend bagi tipe investor yang risk averse atau mendapat return berupa capital gain bagi tipe investor risk taker. Menurut Putra dan Arfan (2013) para investor tidak suka 
menerima return dibagikan dalam bentuk Dividend, melainkan mereka lebih menyukai capital gain. Hasil penelitian Putra dan Arfan (2013) menunjukan hasil rata-rata abnormal return dari emiten yang mengumumkan Dividend kas menurun pada periode setelah pengumuman Dividend kas meningkat dibandingkan dengan periode sebelum pengumuman Dividend kas.

Menurut Selamat (2016) para investor lebih suka menerima return dalam bentuk Dividend dari pada return dalam bentuk capital gain. Hasil penelitian Selamat (2016) menunjukan perubahan volume transaksi saham sebelum dan sesudah ex-Dividend date yang menurun. Berdasarkan pernyataan tersebut dapat terlihat dari perubahan volume transaksi saham sebelum ex-Dividend date yang menurun dapat disimpulkan bahwa sebagian investor lebih menyukai return dalam bentuk Dividend daripada capital gain.

Berdasarkan uraian diatas, maka dapat dirumuskan hipotesis penelitian sebagai berikut:

$\mathrm{H}_{1}$ : Terdapat perbedaan volume saham sebelum dan sesudah ex-Dividend date pada emiten yang termasuk di LQ-45 selama tahun 2017

\section{METODE PENELITIAN}

Populasi yang digunakan pada penelitian ini adalah adalah perusahaan go public yang terdaftar di Bursa Efek Indonesia yang terdaftar di LQ-45 tahun 2017. Obyek dalam penelitian ini adalah perusahaan-perusahaan yang melakukan kebijakan cash Dividend yang terdaftar di Bursa Efek Indonesia khususnya pada indeks LQ-45 periode 2017. Metode penentuan sampel yang digunakan pada penelitian ini adalah teknik nonprobability sampling dengan metode purposive 
sampling dengan kriteria sebagai berikut; Perusahaan yang terdaftar dalam indeks saham LQ45 di Bursa Efek Indonesia (BEI) periode 2017 dan Membagikan Dividend tunai atau kas Dividend selama periode penelitian yang dilakukan.

Secara rinci pemilihan sampel penelitian akan disajikan pada tabel 1 sebagai berikut.

Tabel 1.

Penentuan Jumlah Sampel

\begin{tabular}{clc}
\hline No & Keterangan & Jumlah \\
\hline 1 & Perusahan yang tergabung dalam indeks LQ45 tahun 2017 & 90 \\
2 & Perusahan yang tidak melakukan aksi pembagian Dividend tunai & -44 \\
\hline & TOTAL SAMPEL & 46 \\
\hline
\end{tabular}

Sumber: Data diolah, 2018

Berdasarkan Tabel 1, maka diperoleh jumlah perusahaan yang memenuhi kriteria penentuan sampel untuk penelitian ini sebanyak 46 perusahaan.

Definisi operasional variabel-variabel yang digunakan dalam penelitian ini adalah sebagai berikut:

Volume perdagangan saham diukur dengan Trading Volume Activity (TVA) dengan membandingkan jumlah saham perusahaan yang diperdagangkan dengan jumlah saham yang beredar. Setelah itu, rata-rata masing-masing volume perdagangan saham antara sebelum dan sesudah ex-Dividend date dihitung untuk mengetahui besarnya perbedaan.

$$
T V A=\frac{\text { Jumlah saham yang diperdagangkan }}{\text { Jumlah saham yang beredar }}
$$

Dividend kas perusahaan yang diklasifikasikan berdasarkan laporan kebijakan tahunan perusahaan yang terdaftar di LQ45 selama periode 2017. Dividend disini merupakan bentuk pembagian keuntungan perusahaan terhadap 
pemilik perusahaan tersebut dalam bentuk Dividend tunai. Dengan kriteria perusahaan tersebut terdapat di LQ45 selama tahun 2017

Metode pengumpulan data yang digunakan dalam penelitian ini adalah metode observasi nonpartisipan, yaitu teknik pengumpulan data dengan observasi dimana peneliti tidak terlibat langsung dan hanya sebagai pengamat independen (Sugiyono, 2017). Data yang digunakan dalam penelitian ini adalah data kuantitatif yang berupa laporan keuangan perusahaan yang terdaftar dalam indeks saham LQ45 di Bursa Efek Indonesia (BEI) dan data perdagangan saham yang meliputi harga,volume, frekuensi periode 2017. Data tersebut diperoleh dari situs resmi BEI dan TICMI periode 2017 yang diakses melalui situs Bursa Efek Indonesia (www.idx.co.id) dan situs TICMI (www.ticmi.co.id).

\section{HASIL DAN PEMBAHASAN}

Statistik deskriptif digunakan untuk memperoleh informasi mengenai karakteristik variabel-variabel yang digunakan utamanya mengenai rata-rata (mean), nilai maksimum (max), nilai minimum ( $\min$ ) dan deviasi standar (standard deviation). Rata-rata merupakan suatu nilai dalam kumpulan data yang dapat mewakili kumpulan data tersebut. Nilai maksimum merupakan nilai tertinggi yang terdapat pada suatu kumpulan data. Nilai minimum merupakan nilai terendah yang terdapat pada suatu kumpulan data. Deviasi standar menunjukkan seberapa jauh rentangan nilai antara nilai minimum dan maksimum masing-masing variabel. Pada Tabel 2 disajikan hasil pengujian statistik deskriptif dari volume saham sebelum, sesudah dan ketika ex-Dividend date pada emiten yang termasuk di LQ45 selama tahun 2017. 
ISSN: 2302-8556

E-Jurnal Akuntansi Universitas Udayana

Vol.26.1.Januari (2019): 175-190

Tabel 2.

Hasil Uji Statistik Volume Saham Sebelum dan Sesudah Ex-Dividend date

\begin{tabular}{lcccccc}
\hline \multicolumn{2}{c}{ Variabel } & N & Min & Max & Mean & Std. Dev. \\
\hline Volume Saham & Sebelum & 46 & 6458 & 5171425 & 359733 & 777036 \\
Volume Saham & Ex-Dividend Date & 46 & 7642 & 928966 & 200449 & 193368 \\
Volume Saham & Sesudah & 46 & 5767 & 666448 & 152706 & 143718 \\
\hline
\end{tabular}

Sumber: Data diolah,, 2018

Berdasarkan tabel 2 dapat dilihat jumlah data $(\mathrm{N})$ yang digunakan pada

penelitian ini adalah 46 data volume saham sebelum dan sesudah ex-Dividend date pada emiten yang termasuk di LQ-45 selama tahun 2017. Volume saham sebelum, sesudah dan ketika ex-Dividend date.

Nilai rata-rata volume saham sebelum ex-Dividend date selama tahun 2017 sebesar 359733 dengan standar deviasi sebesar 777036. Nilai volume saham yang lebih rendah dari nilai standar deviasi menunjukkan bahwa terdapat tingkat variasi yang tinggi antara nilai maksimum dan minimum. Nilai tertinggi dan terendah volume saham sebelum ex-Dividend date adalah masing-masing sebesar 5171425 dan 6458.

Nilai rata-rata volume saham saat ex-Dividend date selama tahun 2017 sebesar 200449 dengan standar deviasi sebesar 193368. Nilai volume saham yang lebih tinggi dari nilai standar deviasi menunjukkan bahwa terdapat tingkat variasi yang rendah antara nilai maksimum dan minimum. Nilai tertinggi dan terendah volume saham sebelum ex-Dividend date adalah masing-masing sebesar 928966 dan 7642.

Nilai rata-rata volume saham sesudah ex-Dividend date selama tahun 2017 sebesar 152706 dengan standar deviasi sebesar 143718. Nilai volume saham yang lebih tinggi dari nilai standar deviasi menunjukkan bahwa terdapat tingkat variasi yang rendah antara nilai maksimum dan minimum. Nilai tertinggi dan terendah 
volume saham sesudah ex-Dividend date adalah masing-masing sebesar 666448 dan 5767.

Pada uji ini alat analisis yang digunakan adalah Kolmogorov-Smirnov Test dengan taraf signifikansi yang digunakan adalah 5 persen atau 0,05. Data akan dinyatakan berdistribusi normal apabila tingkat signifikansinya lebih besar dari 0,05 dan apabila tingkat signifikansinya lebih rendah maka data akan dinyatakan tidak berdistribusi normal. Hasil uji normalitas selanjutnya akan disajikan pada Tabel 3.

Tabel 3.

Hasil Uji Normalitas

\begin{tabular}{ccccc}
\hline & Variabel & Sig 2 tailed & Taraf sig & Kesimpulan \\
\hline Volume & Sebelum & 0,00 & 0,05 & Tidak normal \\
Volume & Ex-Dividend Date & 0,01 & 0,05 & Tidak normal \\
Volume & Sesudah & 0,00 & 0,05 & Tidak normal \\
\hline \multicolumn{2}{l}{ Sumber: Data diolah,, 2018} & & &
\end{tabular}

Berdasarkan hasil uji normalitas diatas, dapat diketahui bahwa semua data TVA (total volume activity) perusahaan sebelum, saat hari h dan sesudah exdate Dividend memiliki nilai probabilitas yang lebih kecil dari taraf signifikansi $(\alpha=0,05)$ sehingga dapat disimpulkan bahwa keseluruhan data-data TVA (trading volume activity) tidak berdistribusi normal. Oleh karena seluruh data tidak berdistribusi normal, maka alat uji yang digunakan untuk menguji hipotesis penelitian adalah wilcoxon signed ranks test.

Willcoxon digunakan untuk mengisi signifikansi hipotesis komparatif 2 (dua) sampel independen yang berukuran sama dan datanya berbentuk ordinal. Uji ini paling sering digunakan oleh peneliti ketika ingin menghindari asumsi-asumsi dari statistik uji-t (misalnya data sampel mengikuti distribusi normal). 
Pengambilan keputusan didasarkan perbandingan antara nilai Asymp. Sig. dengan tingkat signifikansi $($ alpha $=0,05)$ yang digunakan dalam penelitian ini. Apabila nilai Asymp. Sig. (2-tailed) < 0,05 maka $\mathrm{H}_{0}$ ditolak dan jika Asymp. Sig. (2-tailed) $\geq 0,05$ maka $\mathrm{H}_{0}$ diterima. Hasil uji Wilcoxon Signed Rank Test akan disajikan pada Tabel 4 .

Tabel 4.

Hasil Wilcoxon Signed Rank Test

\begin{tabular}{ccccc}
\hline Variabel & Selisih Rata-Rata & Assym. Sig & Taraf Sig. & Kesimpulan \\
\hline Volume & $-4,321$ & 0,000 & 0,05 & Berbeda Signifikan \\
\hline Sumber: Data diolah,, 2018 & & &
\end{tabular}

Pada Tabel 4, tampak bahwa nilai assym. sig sebesar 0,002 yang lebih kecil daripada 0,05 maka dapat disimpulkan bahwa rata-rata volume perdagangan saham mengalami perbedaan signifikan pasca ex-Dividend date. Nilai selisih ratarata sebesar -4,321 menunjukkan bahwa rata-rata volume perdagangan saham mengalami penurunan pasca ex-Dividend date. Berdasarkan hasil tersebut maka, $\mathrm{H}_{0}$ ditolak dan $\mathrm{H}_{1}$ diterima sehinga dapat disimpulkan bahwa terdapat perbedaan volume perdagangan saham pasca ex-Dividend date saham yang tergabung pada indeks LQ-45 tahun 2017.

Volume perdagangan saham pada penelitian ini menggunakan Trading Volume Activity, TVA merupakan alat ukur yang digunakan untuk melihat likuiditas saham guna melihat respon atau reaksi dari investor terkait dengan suatu peristiwa. TVA dapat diketahui dengan membandingkan antara volume saham yang diperdagangkan pada periode tertentu dengan volume saham yang beredar pada waktu tertentu. 
Berdasarkan hasil pengujian hipotesis menunjukkan bahwa H0 ditolak yang berarti Hi diterima. Hal ini berarti terdapat perbedaan yang signifikan antara volume perdagangan saham sebelum dan sesudah ex-Dividendd date. Hal tersebut ditunjukkan dengan nilai signifikansi $0,000<$ signifikansi 0,05 . Hasil tersebut mengindikasikan bahwa informasi ex-Dividend date merupakan suatu informasi penting bagi investor sehingga dapat mempengaruhi keputusan investor dalam mengambil keputusan untuk menjual atau membeli saham.

Jika dibandingkan dengan sebelum dan sesudah ex-Dividend date, terjadi penurunan pada aktivitas volume perdagangan saham sesudah ex-Dividend date. Hal tersebut ditunjukkan dengan nilai rata-rata (mean) trading volume activity sebelum dan sesudah ex-Dividend date menurun sebesar $-1,153$ setelah peristiwa ex-Dividend date. Hal ini menunjukkan bahwa peristiwa ex-Dividend date mempengaruhi aktivitas volume perdagangan saham dan direspon oleh investor.

Pada saat setelah ex-Dividend date,mayoritas investor cenderung melakukan aksi profit taking yaitu mencari keuntungan dari selisih harga saham dengan Dividend yang di dapat. Aksi tersebut dilakukan setelah investor memastikan mendapat Dividend dengan cara memegang saham sampai sehari sebelum peristiwa ex-Dividend date (cum date), kemudian menjual saham yang dipegangnya tersebut pada saat ex-Dividend date untuk mendapatkan profit. Hal itulah yang menyebabkan banyak investor yang menjual sahamnya pada saat setelah ex-Dividend date sehingga mempengaruhi aktivitas volume perdagangan saham dan akhirnya juga berpengaruh terhadap perubahan harga saham perusahaan. 
Peristiwa tersebut menunjukan bahwa mayoritas investor menganut teori Bird In The Hand, yaitu teori yang dikemukakan oleh Myron Gordon Tahun 1956 dan John Lintner Tahun 1962 menyatakan bahwa investor menghendaki pembayaran Dividend yang tinggi dari keuntungan perusahaan sesuai tujuan investor yaitu menanamkan sahamnya untuk mendapatkan deviden. Investor akan bersedia membayar harga yang lebih tinggi untuk perusahaan yang membayar Dividend saat ini. Pembayaran deviden saat ini terjadi karena ada anggapan bahwa mendapat Dividend saat ini resikonya lebih kecil daripada mendapat capital gain di masa yang akan datang meskipun capital gain di masa mendatang dapat memberikan pengembalian yang lebih tinggi daripada Dividend saat ini. Dari pendapat tersebut yang mendasari perilaku investor yang cenderung melakukan aksi akumulasi sebelum ex-Dividend date yang menyebabkan volume perdagangan saham meningkat sebelum ex-Dividend date.

Hasil penelitian ini juga didukung oleh penelitian yang dilakukan oleh Blandon dan Blasco (2012) yang menyatakan bahwa terdapat perbedaan yang signifikan antara volume perdagangan saham sebelum dan sesudah ex-Dividendd date.

\section{REFERENSI}

Ang, Robert. (1997). Pintar Pasar Modal Indonesia. Jakarta: Mediasoft Indonesia.

Antolis, Teguh dan Dossugi, Samuel. (2008). Pengaruh Fluktuasi IHSG, Inflasi, Dan Suku Bunga Terhadap Imbal Hasil Unitlink Berbasis Saham. Journal of Applied Finance and Accounting, 1(1).

Beaver, William H. (1968). The Information Content of Annual Earnings Announcement. Journal of Accounting Research, 6, 7-92. 
Bhattacharya, Sudipto. (1979). Imperfect Information, Dividend Policy, and "the Bird in the Hand" Fallacy. The Bell Journal of Economics, 10(1), 259-270.

Cambell, John Y. (1988). Stock Prices,Earning, and Expected Dividendds. Journal of Finance,43(3) , 661-676.

Deitiana, Tita. (2011). Pengaruh Rasio Keuangan, Pertumbuhan Penjualan dan Dividend Terhadap Harga Saham. Jurnal Bisnis dan Akuntansi,13(1), 5766.

Dermawan Sjahrial. (2007). Manajemen Keuangan. Jakarta : Mitra Wacana Media.

Dimas Prasetyo, Zahroh Z.A., Devi Farah Azizah. (2013). Pengaruh Keputusan Investasi, Keputusan Pendanaan, dan Kebijakan Deviden Terhadap Nilai Perusahaan (Studi Pada Perusahaan Sektor Properti dan Real Estate yang Terdaftar di Bursa Efek Indonesia Periode 2009-2011). Jurnal Administrasi Bisnis,5(1), 117-124.

Eades, K.M., P.J. Hess, and E.H. Kim. (1984). On Interpreting Security Returns During the Ex-Dividendd Period. Journal of Financial Economic, 13, 3 - 34.

Fajaria, Ardina Zahrah (2015). Pengaruh Keputusan Investasi, Keputusan Pendanaan Dan Kebijakan Dividend Terhadap Nilai Perusahaan. Undergraduate Thesis, Stie Perbanas Surabaya.

Fama, Eugene F. (1970). Efficient Capital Markets: A Review of Theory and Empirical Work. The Journal of Finance, 25(2), 383-417.

Ferdiansyah F. (2012). Pengaruh Keputusan Pendanaan, Keputusan Investasi dan Kebijakan Dividend Terhadap Nilai Perusahaan Pada Industri Food And Beverage Yang Listing Di Bursa Efek Indonesia Periode 2007-2011. Jurnal Widya Manajemen \& Akuntansi, 5(3), 13-35.

Garcia-Blandon, Josep, \& Martinez-Blasco, Monica. (2012). The Ex-Dividend Day Anomaly in the Spanish Stock Market. Journal of CENTRUM, 5(1), 102-114.

Huang, Yuan \& Xiao Li. (2014). Information Content of Annual Earnings Announcements: A Comparative Study. China Accounting and Finance Review, 16(2), 171-182.

Jagannathan, R. \& Frank, M. (1997), Why Do Stock Price Drop by Less than the Value of Value the Dividendd? Evidence from a Country Without Taxes, Journal of Financial Economic, 47, 161-188. 
Jogiyanto H.M. (2015). Teori Portofolio dan Analisis Investasi. Edisi Ketujuh. Yogyakarta: BPFE.

Khan, Kanwal Iqbal. (2012). Effect of Dividends on Stock Prices- A Case of Chemical and Pharmaceutial Industri of Pakistan. Management, 2(5), 141148.

Majanga, Byson B. (2015). The Dividend Effect on Stock Price. Accounting and Finance Research,4(3), 99-105.

Michaely, R. (1991). Ex-Dividendd Day Stock Price Behavior : The Case of the 1986 Tax Reform Act, Journal of Finance, 46(3), 845-859.

Nany, Magdalena. (2004). Analisis Pengaruh Harga Saham, Return Saham, Varian Return Saham, Earnings Dan Volume Perdagangan Saham Terhadap Bid Ask Spread Sebelum Dan Sesudah Pengumuman Laporan Keuangan (Studi Empiris Pada Saham LQ 45 Di Bursa Efek Jakarta). Jurnal Perspektif 9(1). 23-31.

Nurmayanti, Poppy. (2009). Pengaruh Return Saham, Earnings, Dan Volume Perdagangan Saham Terhadap Bid Ask Spread Sebelum Dan Sesudah Pengumuman Laporan Keuangan. Pekbis 1(2).

Ong, Erdianto (2016) Technical Analysis for Mega Profit. Jakarta: Gramedia Pustaka Utama.

Prihantoro. (2003). Estimasi Pengaruh Dividendd Payout Ratio pada perusahaan publik di indonesia. Jurnal Ekonomi dan Bisnis. 1(8). 7-14.

Ruslianti,Ellen dan Nur Farida,Esti. (2010). Pemecahan Saham Terhadap Likuiditas dan Return Saham. Jurnal Bisnis dan Akuntansi. 12(3). 161-174.

Sharif, et al. (2015) , Effect of Dividendd Policy on Stock Prices. Journal of Mangement Inf,6(1), 55-81.

Selamat, Melani Ali. (2017), Perilaku Harga Saham, Volume Perdagangan Saham, Dan Abnormal Return Sebelum Dan Sesudah Ex-Dividend Date. Skripsi Fakultas Ekonomi Dan Bisnis Universitas Islam Negeri Syarif Hidayatullah Jakarta.

Sugiyono. (2009). Metode Penelitian Bisnis. Edisi Kesepuluh. Bandung: CV Alfabeta. 
Byantoro Istahargyo dan Made Gede Wirakusuma. Analisis...

Sularso, R. Andi. (2003). pengaruh pengumuman dividend terhadap perubahan harga saham (return) sebelum dan sesudah ex -dividend date di bursa efek jakarta (BEJ). Jurnal Akuntansi \& Keuangan, 5(1), 1-17.

Susilowati, Yeye. (2011). Reaksi Signal Rasio Profitabilitas Dan Rasio Solvabilitas Terhadap Return Saham Perusahaan. Dinamika keuangan dan Perbankan 3(1). 17 - 37.

Weston, Fred J., \& Eugene F. Brigham. (2005). Dasar-Dasar Manajemen Keuangan. Jilid 2, 9th ed. Jakarta: Erlangga.

Weston, J. Fred, Copeland, Thomas. E. (1992). Manajemen Keuangan. Edisi Kedelapan. Dialihbahasakan oleh Jaka Wasana dan Kirbandoko. Jakarta: Binarupa Aksara. 